\title{
Supercritical Fluid Impregnation of Essential Bark Oil in Copolymers of L-Lactide with 7-Membered Cyclic Compounds
}

\author{
Chikara Tsutsumi ${ }^{*}$, Teruyuki Hara1, Yuka Ueno', Yuushou Nakayama², Takeshi Shiono ${ }^{2}$ \\ ${ }^{1}$ Department of Applied Chemistry and Biotechnology, Niihama National College of Technology, Niihama, \\ Japan \\ ${ }^{2}$ Department of Applied Chemistry, Graduate School of Engineering, Hiroshima University, Higashi-Hiroshima, \\ Japan \\ Email: ${ }^{*}$ tsutsumi@chem.niihama-nct.ac.jp
}

Received 26 March 2014; revised 29 May 2014; accepted 25 June 2014

Copyright (C) 2014 by authors and Scientific Research Publishing Inc.

This work is licensed under the Creative Commons Attribution International License (CC BY). http://creativecommons.org/licenses/by/4.0/

\section{(c) (i) Open Access}

\section{Abstract}

In order to develop a novel controlled-release material, we previously attempted to impregnate poly(L-lactide) (poly(L-LA)), poly(L-LA-ran-CL) (CL: $\varepsilon$-caprolactone) or poly(L-LA-ran-TEMC) (TEMC: tetramethylene carbonate) with low boiling point, organic useful compounds using supercritical carbon dioxide $\left(\mathrm{scCO}_{2}\right)$ as the solvent. In this work, the factors influencing impregnation of poly (L-LA) random copolymers with useful compounds were investigated under $\mathrm{scCO}_{2}$ using the copolymers previously used. The influence of temperature, pressure, and time on the impregnation contents of the useful compounds on the copolymers was evaluated. The polymer used, which is a base of this material, was poly(L-LA-ran-CL), poly(L-LA-ran-TEMC), or poly(L-LA-ran-DXO) (DXO: 1,5-dioxepan-2-one). Statistical random copolymers of L-LA with CL, TEMC, or DXO were synthesized using $\operatorname{Sn}(o c t)_{2}$ as a catalyst at $150^{\circ} \mathrm{C}$ for $24 \mathrm{~h}$ without solvent. Preparation of the controlled-release materials was carried out using essential bark oil from Thujopsis dolabrata var. hondae and synthetic L-LA random copolymers as a base material under $\mathrm{scCO}_{2}$. The impregnation experiment, which investigated the influence of pressure, was conducted in the range of 10 to 20 MPa. The influence of temperature on impregnation was carried out at $40^{\circ} \mathrm{C}$ to $100^{\circ} \mathrm{C}$. Impregnation time was varied from 1 to $5 \mathrm{~h}$. The pressure of essential oil impregnated into poly(L-LA) random copolymers was the highest at $14 \mathrm{MPa}$. In the influence of temperature on impregnation, the amount of essential oil increased with increasing temperature.

\footnotetext{
${ }^{*}$ Corresponding author.
}

How to cite this paper: Tsutsumi, C., Hara, T., Ueno, Y., Nakayama, Y. and Shiono, T. (2014) Supercritical Fluid Impregnation of Essential Bark Oil in Copolymers of L-Lactide with 7-Membered Cyclic Compounds. Journal of Biomaterials and Nanobiotechnology, 5, 159-172. http://dx.doi.org/10.4236/jbnb.2014.53019 


\section{Keywords}

\section{Biodegradable Polyester, L-Lactide Copolymer, Supercritical Carbon Dioxide, Impregnation}

\section{Introduction}

Prevention of the reproduction and extermination of food poisoning bacteria, inhibition of molds that grow on walls, furniture, and inside buildings, such as houses, museums, etc. and extermination of insect pests and animals on farms or parks is a serious social problem. The control material using an evasion ingredient toward such as microorganism is developed [1] [2]. It is also known that Reticulitermes speratus deteriorates structural lumber, such as pillars of wooden structures. Consequently, structural lumber rots away internally, and eroded wooden structures might collapse if an earthquake occurs. Remedies for these problems are chemical control, physical prevention of growth, extermination, biotic control, etc. The conventional chemical control has the great influence affect environment and living, use of the natural origin compounds with lower load for them is desired. It is also known that essential bark oil from Thujopsis dolabrata var. hondae is highly toxic to Reticulitermes speratus. The oil has the effect of antibacterial, spiritual stabilizing and deodorization other than insect control. From above features, this oil is used for medical treatment, sanitary, agriculture, and food. Since this oil is volatility, there is no durability in an effect. In order to make it volatilize gently, and maintain an effect for a long period of time, it is suitable to the use as a controlled release drug. DDS (drug delivery system) is material with controlled-release and is usually studied as a medical material etc. [3]-[7].

DDS is using biodegradable polymer as base material, in order to acquire controlled-release. Although DDS preparation technology is suitable for producing a microcapsule by emulsification in polymer and hydrophilic drug, it cannot make a hydrophobic organic compound such as essential oil take into polymer. Generally as for the method of making an organic compound taking into polymer, the immersion method, the mulling method and the solvent dissolution method are used. However, the methods have the following problems.

The immersion method is a method in which porous resin and a narrow tube are made to immerse chemicals, and preparation of porous resin, a fast chemicals release rate, and the uneven release are problems. Also, chemicals release which is volatility is affected by temperature in the method. Although the mulling method can mix high boiling point compounds in polymer, low boiling points which volatilizes at processing temperature cannot be taken in. Moreover, the solvent dissolution method is subject to problems such as volatilization of the agent at the time of solvent removal and the presence of residual organic solvents. A large quantity of solvents will be used for this method, and it is not suitable for industrialization.

In order to solve the above problems, the method of taking efficiently into the polymer material of low boiling points which does not use an organic solvent and selection of the polymer which has the highly efficient release ability replaced with porosity resin are required. In how to take in the polymer, as to suppress volatilization of the low boiling points and the lower of the physical properties of the polymer by heat which is a problem of the mulling method, it decided to apply the processing method using a supercritical fluid (SCF). SCF is known as a solvent which dissolves organic compound and is well studied [8] [9]. On the other hands, in selection of a polymer, since it became important to be low load to environment and spontaneously degraded by external environment factors, such as humidity, biodegradable polymer was picked out. Although many biodegradable polymers have been studied, poly(L-lactide) is used for medical material in them as polymer which has hydrolysis property [10] [11].

It is well known that supercritical fluid has some unique properties such as liquid-like dissolving capability and transportation properties similar to a gas. $\mathrm{CO}_{2}$, a nontoxic fluid with a relatively low critical point (Tc = $\left.31.1^{\circ} \mathrm{C}, P c=7.376 \mathrm{MPa}\right)$, is most widely used as a supercritical fluid. Supercritical $\mathrm{CO}_{2}\left(\mathrm{scCO}_{2}\right)$ called "Green Solvent" has been used in a variety of industries, including plastics, chemical, pharmaceutical, and food. In the plastics industry, $\mathrm{scCO}_{2}$ has been used for various polymer-processing purposes such as polymer blending [12] [13], polymer foaming [14] [15], preparation of microcapsules [16] [17], and additive impregnation [18] [19]. It can be said that the critical point of $\mathrm{CO}_{2}$ is suitable for processing of polymer.

We have carried out research made to impregnate a volatile compound to biodegradable polymer using $\mathrm{CO}_{2}$ [20]-[22]. In this work, the experiment made to impregnate essential bark oil from Thujopsis dolabrata var. 
hondae to biodegradable random copolymer was conducted under $\mathrm{scCO}_{2}$, and impregnation conditions such as pressure, temperature, and process time were studied. Three kinds of copolymers of L-LA with CL ( $\varepsilon$-caprolactone) [20]-[24], TEMC (tetramethylene carbonate) [21] [22] [25]-[27], or DXO (1,5-dioxepan-2-one) [22] [28] were used in this work.

\section{Experimental}

\subsection{Materials}

L-Lactide (L-LA) [(3S)-cis-3,6-dimethyl-1,4-dioxane-2,5-dione] (Aldrich) was purified by recrystallization from THF followed by sublimation at $80^{\circ} \mathrm{C}$. $\varepsilon$-Caprolactone (CL) (Wako Pure Chem. Ind., Ltd.) was purified by distillation under reduced pressure. Tetramethylene carbonate (TEMC) [1,3-dioxepan-2-one] and 1,5-dioxepan-2one (DXO) (Tokyo Chemical Industry Co., Ltd.) was purified by recrystallization from THF. Tin 2-ethyl-hexanoate $\left[\mathrm{Sn}(\mathrm{oct})_{2}\right]$ (Sigma) was used as a catalyst without purification. Methanol and chloroform were purchased from Katayama Chem. Ind. Co., Ltd. Poly(L-lactide) (LACEA H-100) was received as a gift from Mitsui Chemicals, Inc. Essential bark oil from Thujopsis dolabrata var. hondae (essential oil), purchased from Sugiyama Mokuzai K. K. (Aomori, Japan), was used without purification.

\subsection{Characterization of Polymers}

Using chloroform as an eluent, the number- and weight-average molecular weights of the synthetic copolymers were determined by gel permeation chromatography (GPC) using a Hitachi D-2520 chromatograph equipped with Shodex GPC K-802.5 and K- 804 columns at $40^{\circ} \mathrm{C}$. The flow rate was $1.0 \mathrm{~mL} / \mathrm{min}$. The copolymer was detected with a refractive index detector (RI). The molecular weights were determined with reference to a polystyrene standard.

The thermal characteristics (melting point $T_{\mathrm{m}}$, glass transition point $T_{\mathrm{g}}$, and heat of fusion $-\Delta H_{\mathrm{m}}$ ) were obtained using a Rigaku Thermo Plus 2/DSC8230 differential scanning calorimeter. Samples were heated at a rate of $10^{\circ} \mathrm{C} / \mathrm{min}$ from $-100^{\circ} \mathrm{C}$ to $200^{\circ} \mathrm{C}$ in a nitrogen stream. $T_{\mathrm{m}}$ and $-\Delta H_{\mathrm{m}}$ were determined in the first heating and $T_{\mathrm{g}}$ in the second heating.

The compositions of L-LA with other cyclic monomers (CL, TEMC, or DXO) were determined by ${ }^{1} \mathrm{H}$ NMR spectroscopy using a JEOL JNM-ECP $400 \mathrm{MHz}$ spectrometer. The content of essential oil incorporated into the copolymer was also determined by ${ }^{1} \mathrm{H}$ NMR spectrometry. Chemical shifts were determined relative to residual chloroform at $7.27 \mathrm{ppm}$.

\subsection{Synthesis of Poly(L-LA) Random Copolymers}

All polymerizations were carried out under an argon atmosphere using standard Schlenk techniques. Cyclic monomer copolymerized with L-LA was used with CL, TEMC, and DXO. Copolymerization of L-LA with CL was performed with $\mathrm{Sn}(\mathrm{oct})_{2}\left(3.33 \times 10^{-2} \mathrm{~mol} \%\right.$ of monomer) as a catalyst at $150^{\circ} \mathrm{C}$ for $24 \mathrm{~h}$ (Scheme 1$)$. The

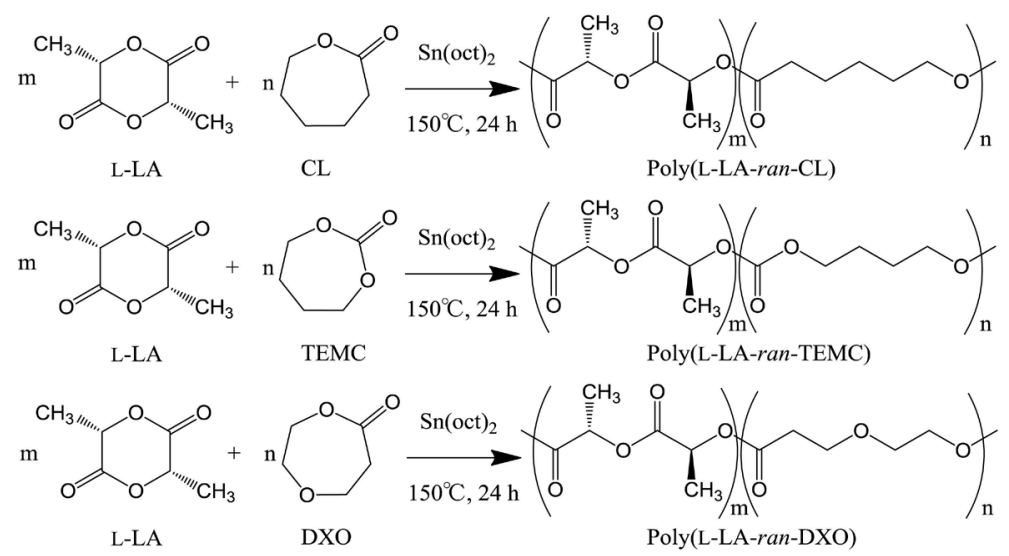

Scheme 1. Copolymerization of L-LA with 7-membered cyclic monomers by $\operatorname{Sn}(\mathrm{oct})_{2}$. 
resulting mixture was dissolved in chloroform and then poured into excess methanol in order to precipitate the resulting polymer. The polymer was dried under reduced pressure. In a similar manner, the copolymerization of L-LA with TEMC or DXO was carried out at $150^{\circ} \mathrm{C}$ for $24 \mathrm{~h}$ (Scheme 1). The molecular weights, compositions, and thermal properties of the obtained copolymers were determined by GPC, ${ }^{1} \mathrm{H}$ NMR spectrometry, and DSC, respectively.

\subsection{Incorporation of Essential Bark Oil into Poly(L-LA) Random Copolymers Using $\mathrm{scCO}_{2}$}

Poly(L-LA) random copolymers were used in the form of a film (thickness, $100 \mu \mathrm{m}$ ). Films of synthetic copolymers were prepared by the solvent-casting method. Impregnation of poly(L-LA) random copolymers with essential oil was carried out inside a pressure-resistant container made from stainless steel $(0.5 \mathrm{~L})$ with stirring (100 rpm) under $\mathrm{scCO}_{2}$, using a high-pressure reaction apparatus (MMJ-500, OM Lab-Tech Co., Ltd.) equipped with a non-pulsating flow pump (NP-KX-500, Nihon Seimitsu Kagaku Co., Ltd.). Pressure, temperature, and time were set up arbitrarily. For the effect of pressure in the impregnation experiment, the pressure was varied in the range of 10 to $20 \mathrm{MPa}$ at $40^{\circ} \mathrm{C}$ for $3 \mathrm{~h}$. For the effect of temperature, the temperature was varied in the range of $40^{\circ} \mathrm{C}$ to $100^{\circ} \mathrm{C}$ at $14 \mathrm{MPa}$ pressure for $3 \mathrm{~h}$. For the effect of time, the pressure (14 MPa) and temperature $\left(40^{\circ} \mathrm{C}\right)$ were fixed and the time was varied from 1 to $5 \mathrm{~h}$. After processing, decompression was carried out gradually over $3 \mathrm{~h}$, and then the sample was removed from the container and weighed. Since the sample contained large amounts of $\mathrm{CO}_{2}$ after impregnation, the content of the essential oil was determined by ${ }^{1} \mathrm{H}$ NMR spectrometry. The amount present was calculated, which was then used to evaluate the experimental value.

\section{Results and Discussion}

\subsection{Synthesis of Poly (L-LA-Ran-7-Membered Cyclic Monomer)}

We previously reported on a study of the impregnation of poly(L-LA-ran-lactone), poly(L-LA-ran-cyclic carbonate), and poly(L-LA-ran-cyclic ester-ether) with $d$-limonene, hinokitiol, trans-2-hexenal, and $\alpha$-pinene using supercritical carbon dioxide $\left(\mathrm{scCO}_{2}\right)$ [20]-[22]. In this work, essential bark oil from Thujopsis dolabrata var. hondae (essential oil) was the compound used for impregnation. In addition, the effects of the polymer structure of the L-LA random copolymers and of the treatment conditions under $\mathrm{scCO}_{2}$ on impregnation with essential oil were studied. CL, TEMC, and DXO were used as 7-membered cyclic monomer copolymerized with L-LA. The treatment conditions were evaluated about impregnation temperature, pressure, and time.

Copolymerization of L-LA with 7-membered cyclic monomers were carried out using $\mathrm{Sn}(\mathrm{oct})_{2}$ as a catalyst $\left(3.33 \times 10^{-2} \mathrm{~mol} \%\right.$ of monomer) in order to investigate the impregnation. Table 1 lists the results of synthesis of

\begin{tabular}{|c|c|c|c|c|c|c|c|c|}
\hline Copolymer & Feed ratio & Yield [\%] & $M_{\mathrm{n}} / 10^{4 \mathrm{~b}}$ & $M_{\mathrm{w}} / M_{\mathrm{n}}^{\mathrm{b}}$ & Composition $^{c}$ & $T_{\mathrm{m}}{ }^{\mathrm{d}}\left[{ }^{\circ} \mathrm{C}\right]$ & $-\Delta H_{\mathrm{m}}{ }^{\mathrm{d}}[\mathrm{J} / \mathrm{g}]$ & $T_{\mathrm{g}}^{\mathrm{d}}\left[{ }^{\circ} \mathrm{C}\right]$ \\
\hline \multirow[t]{4}{*}{ L-LA/CL } & $90 / 10$ & 88.3 & 7.1 & 1.71 & $91 / 9$ & 152.7 & 24.9 & 48.3 \\
\hline & $90 / 10^{\mathrm{e}}$ & 87.1 & 5.0 & 1.81 & $88 / 12$ & 154.0 & 28.6 & 45.5 \\
\hline & $80 / 20$ & 82.5 & 6.8 & 1.89 & $83 / 17$ & 145.8 & 23.4 & 38.7 \\
\hline & $70 / 30$ & 80.9 & 5.0 & 1.75 & $72 / 28$ & 138.9 & 19.6 & 25.5 \\
\hline \multirow[t]{3}{*}{ L-LA/TEMC } & $90 / 10$ & 91.2 & 7.6 & 1.74 & $88 / 12$ & 129.0 & 14.6 & 51.1 \\
\hline & $90 / 10^{\mathrm{e}}$ & 88.6 & 5.6 & 1.65 & $86 / 14$ & 127.4 & 6.9 & 49.3 \\
\hline & $80 / 20$ & 85.3 & 6.2 & 1.51 & $76 / 24$ & 107.4 & 8.2 & 28.4 \\
\hline \multirow[t]{4}{*}{ L-LA/DXO } & $90 / 10$ & 86.7 & 5.1 & 1.64 & $90 / 10$ & 154.9 & 36.7 & 50.3 \\
\hline & $80 / 20$ & 90.9 & 5.4 & 1.52 & $82 / 18$ & 142.6 & 18.2 & 37.1 \\
\hline & $80 / 20^{\mathrm{e}}$ & 88.2 & 5.4 & 1.39 & $75 / 25$ & 119.3 & 16.2 & 25.4 \\
\hline & $70 / 30$ & 83.8 & 6.9 & 1.64 & $73 / 27$ & 126.6 & 6.1 & 26.9 \\
\hline Poly(L-LA) & $100 / 0^{\mathrm{f}}$ & - & 9.0 & 1.64 & $100 / 0$ & 169.3 & 32.0 & 59.6 \\
\hline
\end{tabular}

${ }^{\mathrm{a}}$ Copolymerization was carried out with $\mathrm{Sn}(\mathrm{oct})_{2}\left(3.33 \times 10^{-2} \mathrm{~mol} \%\right.$ of monomer $)$ at $150^{\circ} \mathrm{C}$ for $24 \mathrm{~h}$; ${ }^{\mathrm{b}}$ Determined by GPC; ${ }^{\mathrm{c}}$ Determined by ${ }^{1} \mathrm{H}$ NMR spectroscopy; ${ }^{\mathrm{d}}$ Determined by DSC; ${ }^{\mathrm{e}} \mathrm{Sn}(\mathrm{oct})_{2}\left(5.00 \times 10^{-2} \mathrm{~mol} \%\right.$ of monomer); ${ }^{\mathrm{f}} \mathrm{Poly}$ (L-lactide) (LACEA H-100, Mitsui Chemicals, Inc.). 
L-LA copolymers at $150^{\circ} \mathrm{C}$ for $24 \mathrm{~h}$. Copolymerization of L-LA with CL at a feed ratio of 90/10 gave a number-average molecular weight $\left(M_{n}\right)$ of the $7.1 \times 10^{4}$, and was able to synthesize a polymer of a comparatively higher molecular weight. The obtained copolymer had a composition (91/9) that was almost the same as the feed ratio. Based on DSC measurements, $T_{\mathrm{m}},-\Delta H_{\mathrm{m}}$, and $T_{\mathrm{g}}$ (thermal properties) of the poly(L-LA-ran-CL) (91/9) were determined to be $152.7^{\circ} \mathrm{C}, 24.9 \mathrm{~J} / \mathrm{g}$, and $48.3^{\circ} \mathrm{C}$, respectively, indicating a higher crystalline polymer. These values decreased as the L-LA content was reduced. In the copolymer of L-LA with CL at a feed ratio of 80/20, poly(L-LA-ran-CL) (83/17) was obtained in $6.8 \times 10^{4}$ of $M_{\mathrm{n}}$ in an $82.5 \%$ yield. Although the copolymer was the same molecular weight as poly(L-LA-ran-CL) (91/9), the thermal properties were lower. The cause for this is considered to be the composition of the copolymer. As a reference, the measured properties of poly (L-LA) (LACEA H-100) are listed in Table 1. The polymer had a higher molecular weight of $9.0 \times 10^{4}$, and $T_{\mathrm{m}}$ and $T_{\mathrm{g}}$ were $169.3^{\circ} \mathrm{C}$ and $59.6^{\circ} \mathrm{C}$, respectively. In addition, poly (L-LA) was a high crystalline polymer with $-\Delta H_{\mathrm{m}}$ of $32.0 \mathrm{~J} / \mathrm{g}$.

Next, copolymerization of L-LA with TEMC was carried out using Sn(oct $)_{2}$ as well as poly(L-LA-ran-CL). The copolymers synthesized at feed ratios of 90/10 and 80/20 were obtained in higher molecular weights, $7.6 \times$ $10^{4}$ and $6.2 \times 10^{4}$ of $M_{\mathrm{n}}$, respectively. $M_{\mathrm{n}}$ of the copolymer (86/14) synthesized at a catalyst concentration of $5.00 \times 10^{-2} \mathrm{~mol} \%$ was lower than one of the copolymer (88/12) synthesized at $3.33 \times 10^{-2} \mathrm{~mol} \%$ as poly (L-LA-ran-CL), indicating that it be dependent on the monomer catalyst ratio. Poly(L-LA-ran-TEMC) (88/12) showed $T_{\mathrm{m}}$ of $129.0^{\circ} \mathrm{C},-\Delta H_{\mathrm{m}}$ of $14.6 \mathrm{~J} / \mathrm{g}$, and $T_{\mathrm{g}}$ of $51.1^{\circ} \mathrm{C}$ by DSC measurement. $T_{\mathrm{g}}$ was high, although $T_{\mathrm{m}}$ and $\Delta H_{\mathrm{m}}$ were low, compared with the same $M_{\mathrm{n}}$ and composition of poly(L-LA-ran-CL). In the synthesis of the conventional L-LA copolymer, there was a tendency for $T_{\mathrm{m}}$ and $\Delta H_{\mathrm{m}}$ to increase with a lower $M_{\mathrm{n}}$ with the same composition. In this work, it is assumed that TEMC is a factor affecting the greater reduction of $T_{\mathrm{m}}$ and $\Delta H_{\mathrm{m}}$ of poly(L-LA) than that of CL.

Third, the results of copolymerization of L-LA with DXO at $150^{\circ} \mathrm{C}$ for $24 \mathrm{~h}$ are shown in Table 1 . The yield and $M_{\mathrm{n}}$ of the copolymer, which was synthesized at ratio of $90 / 10$, were $86.7 \%$ and $5.1 \times 10^{4}$, respectively, and the copolymer could be obtained with comparatively higher $M_{\mathrm{n}}$ at high yield. For DSC measurement, $T_{\mathrm{m}}$ and $T_{\mathrm{g}}$ of poly(L-LA-ran-DXO) (90/10) were slightly higher than that of poly(L-LA-ran-CL) at almost the same composition. When copolymerization was performed at a catalyst concentration of $5.00 \times 10^{-2} \mathrm{~mol} \%$ at a feed ratio of 80/20, the L-LA content in the copolymer fell easier than did the L-LA feed. Although $M_{\mathrm{n}}$ of the copolymer (75/25) was the same as that of the 82/18 composition, since the L-LA content was lower, the values of the thermal properties were low.

\subsection{Effect of Pressure on Impregnation of Poly(L-LA) Random Copolymers with Essential Oil Extracted from Thujopsis dolabrata var, hondae Using $\mathrm{scCO}_{2}$}

In order to consider the effect of the pressure exerted on the essential oil used to impregnate various poly(L-LA) random copolymers under $\mathrm{scCO}_{2}$, impregnation was conducted in the range of 10 to $20 \mathrm{MPa}$ at a fixed temperature of $40^{\circ} \mathrm{C}$ and time of $3 \mathrm{~h}$. The synthesized poly(L-LA) random copolymers described above were made into film (thickness $100 \mu \mathrm{m}$ ) using the solvent-casting method. The results of impregnation of the oil into poly(L-LA) random copolymers are shown in Figure 1.

Although impregnation of the essential oil into poly(L-LA) was $4.4 \%$ at $10 \mathrm{MPa}$, the oil content increased abruptly with an increase in pressure over $12 \mathrm{MPa}$, reaching a maximum of $7.4 \%$ at $14 \mathrm{MPa}$. The content decreased over $14 \mathrm{MPa}$, and was $5.8 \%$ at $20 \mathrm{MPa}$. This shows that the effect of pressure is barely seen over 17 MPa. It is clear that the oil content increases with an increase of CL content in poly(L-LA-ran-CL) in conventional experiments at $20 \mathrm{MPa}$ and $40^{\circ} \mathrm{C}$ for $3 \mathrm{~h}$ [22]; the same result was also expected in this work. It is known that the density of $\mathrm{scCO}_{2}$ increases with the rise of pressure and the solubility of a compound will also increase in connection with it. Although it was expected that the oil content became the maximum at 20MPa, in the experiment, the content was the highest at $14 \mathrm{MPa}$. In impregnation experiment, although impregnation of the essential oil into polymer is caused, the oil contained in polymer is extracted simultaneously by $\mathrm{scCO}_{2}$. Therefore, when pressure is high, it is thought that $\mathrm{scCO}_{2}$ will give priority to extraction than impregnation. The essential oil content of poly(L-LA-ran-CL) (83/17) was $5.9 \%$ at $10 \mathrm{MPa}$, and was a maximum of $9.2 \%$ at $14 \mathrm{MPa}$. The content decreased with an increase in pressure over $14 \mathrm{MPa}$, and was $6.1 \%$ at $20 \mathrm{MPa}$. In poly(L-LA-ran-CL) (72/28), the content increased more than in the other copolymers in the pressure region of 10 to $17 \mathrm{MPa}$. Furthermore, poly(L-LA-ran-CL) (72/28) showed a maximum of $12.8 \%$ at $14 \mathrm{MPa}$. Although the impregnation 


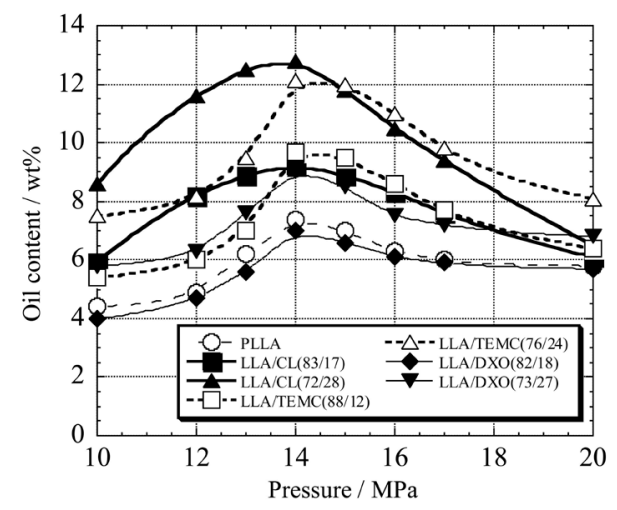

Figure 1. Effect of pressure on impregnation of L-LA copolymer films with essential oil using $\mathrm{scCO}_{2}$ at $40^{\circ} \mathrm{C}$ for $3 \mathrm{~h}$.

experiment was only conducted at $20 \mathrm{MPa}$ in previous experiments [20]-[22], in this work, pressure greatly affected the content of essential oil.

The oil content of poly(L-LA-ran-TEMC) at composition 88/12 was higher than that of poly(L-LA); it was $5.4 \%$ at $10 \mathrm{MPa}$. As was also observed in the impregnation experiment of poly(L-LA-ran-CL), the oil content of poly(L-LA-ran-TEMC) (88/12) increased with a rise in pressure, reaching a maximum of 9.7\% at $14 \mathrm{MPa}$. In the pressure range of 10 to $20 \mathrm{MPa}$, the oil content of poly(L-LA-ran-TEMC) $(76 / 24)$ was also $12.1 \%$ of the maximum at $14 \mathrm{MPa}$, and was higher than the copolymer (88/12). Although the impregnation curve of the copolymer (76/24) was similar with that of poly(L-LA) or the copolymer (88/12), it differed from the curve of poly (L-LA-ran-CL). Poly(L-LA-ran-TEMC) (76/24) dissolved slightly by processing for $3 \mathrm{~h}$ at $40^{\circ} \mathrm{C}$ regardless of pressure. The cause is thought to be that $T_{\mathrm{m}}$ and $\Delta H_{\mathrm{m}}$ of poly(L-LA-ran-TEMC) are lower than that of poly (L-LA-ran-CL). In a previous study, it has reported that $T_{\mathrm{m}}$ and $\Delta H_{\mathrm{m}}$ affect the maintenance of form and content [21] [22]. The above results showed that the differences in oil content in poly(L-LA-ran-CL) and poly(LLA-ran-TEMC) resulted from the effect of pressure.

In the impregnation of poly(L-LA-ran-DXO), the oil content of copolymer at composition 82/18 was lower than that of poly(L-LA) in all pressure regions. Although the content of the copolymer (82/18) showed a maximum of $7.0 \%$ at $14 \mathrm{MPa}$ and was lower with $4.0 \%$ at $10 \mathrm{MPa}$, it had the lowest value among the three kinds of copolymers used. The impregnation curve of poly(L-LA-ran-DXO) resembled that of poly(L-LA) or poly(LLA-ran-TEMC). Furthermore, the result was that the content in the three kinds of copolymers with L-LA reached maximum at $14 \mathrm{MPa}$ in the incorporation of the oil into the used copolymers under $\mathrm{scCO}_{2}$.

In the relation of content and pressure, in order to discuss what kind of influence $\mathrm{scCO}_{2}$ has had on the physical properties of copolymer, a molecular weight and the thermal characteristic were measured for every different pressure. The following copolymer was used in this experiment. [poly(L-LA-ran-CL) (82/18), $M_{\mathrm{n}} 4.1 \times 10^{4}$, $M_{\mathrm{w}} / M_{\mathrm{n}} 1.92, T_{\mathrm{m}} 142.1^{\circ} \mathrm{C}, \Delta H_{\mathrm{m}} 14.5 \mathrm{~J} / \mathrm{g}, T_{\mathrm{g}} 36.4^{\circ} \mathrm{C}$; poly(L-LA-ran-TEMC) (79/21), $M_{\mathrm{n}} 3.6 \times 10^{4}, M_{\mathrm{w}} / M_{\mathrm{n}} 1.66$, $T_{\mathrm{m}}$ and $\Delta H_{\mathrm{m}}$ not detected, $T_{\mathrm{g}} 37.8^{\circ} \mathrm{C}$; poly(L-LA-ran-DXO) (83/17), $M_{\mathrm{n}} 2.7 \times 10^{4}, M_{\mathrm{w}} / M_{\mathrm{n}} 1.79, T_{\mathrm{m}} 146.8^{\circ} \mathrm{C}$, $\left.\Delta H_{\mathrm{m}} 23.8 \mathrm{~J} / \mathrm{g}, T_{\mathrm{g}} 40.9^{\circ} \mathrm{C}\right]$. First, it experimented about the influence pressure has on a molecular weight (Figure 2). The "before" in Figure or sentence indicates the physical properties of polymer without treatment using $\mathrm{scCO}_{2}$. When poly(L-LA-ran-CL) $(82 / 18)$ was processed at $10 \mathrm{MPa}$ and $40^{\circ} \mathrm{C}$ for $3 \mathrm{~h}$ under scCO $\mathrm{Cl}_{2}$ without essential oil, the $M_{\mathrm{n}}$ of the copolymer was same as processing before. However, at $14 \mathrm{MPa}$, the $M_{\mathrm{n}}$ was the highest and was $4.3 \times 10^{4}$. The $M_{\mathrm{n}}$ at $20 \mathrm{MPa}$ was decreasing rather than the value before processing. The same tendency was shown, and other copolymers were the highest at $14 \mathrm{MPa}$, and the lowest at $20 \mathrm{MPa}$. From the above result, the polymer chains of lower molecular weight are extracted by the extraction effect of $\mathrm{scCO}_{2}$, and the effect resulted in increase of the molecular weight of the copolymer. As mentioned above, pressure and density have a close relation, and the extraction effect becomes higher when pressure is high. Several authors have investigated the extraction and purification of lipid compounds, such as triacylglycerols, free fatty acids, and sterols, using $\mathrm{scCO}_{2}$ [29]-[33]. It is anticipated that lower molecular weight polymer chains are extracted properly at $14 \mathrm{MPa}$, and it seems that the oil which dissolved in the $\mathrm{scCO}_{2}$ effectively replace shorter polymer chains, and is impregnated. 


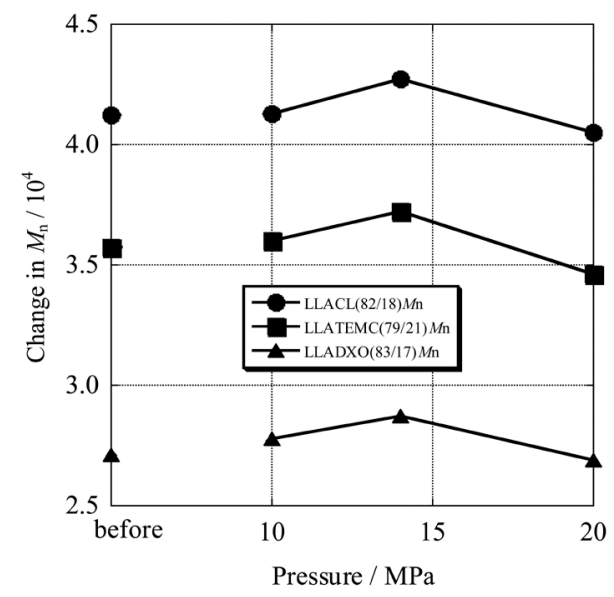

Figure 2. Change of $M_{\mathrm{n}}$ of L-LA copolymers under $\mathrm{ScCO}_{2}$ at $40^{\circ} \mathrm{C}$ for $3 \mathrm{~h}$.

Next, the influence the thermal characteristic of polymer has on the content was studied. The result of the relation between the thermal characteristic $\left(T_{\mathrm{m}}\right.$ and $\Delta H_{\mathrm{m}}$ ) and pressure is shown in Figure 3. Although the $T_{\mathrm{m}}$ of three kinds of copolymers processed with $\mathrm{scCO}_{2}$ became high with the increase of pressure rather than processing before, change was hardly seen over $14 \mathrm{MPa}$. In the heat of fusion, although poly(L-LA-ran-TEMC) (79/21) was amorphous polymer in which the melting point does not exist, the $T_{\mathrm{m}}$ was confirmed after $\mathrm{scCO}_{2}$ processing and the $\Delta H_{\mathrm{m}}$ increased with the increase in pressure. Although poly(L-LA-ran-CL) (82/18) was the almost same tendency, $T_{\mathrm{m}}$ and $\Delta H_{\mathrm{m}}$ did not have a big change below $14 \mathrm{MPa}$. On the other hand, although the heat of fusion of poly(L-LA-ran-DXO) (83/17) was increased like poly (L-LA-ran-TEMC) below $14 \mathrm{MPa}$, it decreased at $20 \mathrm{MPa}$. It became clear that the $\Delta H_{\mathrm{m}}$ differs in the amount of change by one's magnitude and the composition element of the copolymer after $\mathrm{scCO}_{2}$ processing.

The relation between $T_{\mathrm{g}}$ obtained by the second heating and pressure is shown in Figure 4. $T_{\mathrm{g}}$ of all the L-LA copolymers was the tendency to rise rather than processing before, and $T_{\mathrm{g}}$ rose with the increase in pressure further. $T_{\mathrm{g}}$ of poly(L-LA-ran-CL) (82/18) and poly(L-LA-ran-DXO) (83/17) was hardly changed before and after processing using $\mathrm{scCO}_{2}$ as well as change of $T_{\mathrm{m}}$ and $\Delta H_{\mathrm{m}}$. However, $T_{\mathrm{g}}$ of poly(L-LA-ran-TEMC) (79/21) is increased dramatically after processing and it is greatly related to the appearance (Figure 3) of $T_{\mathrm{m}}$. From above results, it is thought that $\mathrm{scCO}_{2}$ is a factor which induces the rearrangement of a polymer chain, and is increased the crystalline domain of the L-LA copolymer. The $\Delta H_{\mathrm{m}}$ of the L-LA copolymersat each pressure was the following order; poly(L-LA-ran-DXO) > poly(L-LA-ran-CL) > poly(L-LA-ran-TEMC). This order appeared to be similar to the impregnation of oil. Although the oil uptake is greatly dependent on crystallinity, it is thought by higher pressure that solubility has also influenced. Since the density of $\mathrm{scCO}_{2}$ is in the tendency to rise with pressure increase, the solubility of polymer or oil is also considered as a factor of impregnation.

\subsection{Effect of Processing Time on Impregnation of Poly(L-LA) Random Copolymers with Essential Oil Using $\mathrm{ScCO}_{2}$}

The effect of processing time on content was considered in the impregnation experiment of the essential oil in various copolymers with L-LA. Figure 5 shows the impregnation experiment for 1 to $5 \mathrm{~h}$ of processing time at $14 \mathrm{MPa}$ and $40^{\circ} \mathrm{C}$. Although the content in poly(L-LA) was $4.0 \%$ for $1 \mathrm{~h}$, the content increased to $7.4 \%$ for $3 \mathrm{~h}$. It was expected that content would increase through the extension of additional time. However, after $5 \mathrm{~h}$, the content barely changed and was $7.0 \%$. The impregnation curve to time for copolymer composition 83/17 or $72 / 28$ was the same as that of poly(L-LA). The copolymer with composition 83/17 or 72/28 showed maximum content for $3 \mathrm{~h}$, and was $9.2 \%$ and $11.5 \%$, respectively. With prolonged processing, the physical properties such as the thermal characteristics changed, so that it was thought that the oil content also changed.

Next, changes of thermal characteristics were observed, and their effect on content was considered. Although $T_{\mathrm{m}}$ and $-\Delta H_{\mathrm{m}}$ of poly(L-LA) were $169.3^{\circ} \mathrm{C}$ and $32.0 \mathrm{~J} / \mathrm{g}$ before processing, respectively, $T_{\mathrm{m}}$ and $-\Delta H_{\mathrm{m}}$ decreased with an extension of processing time and were $166.7^{\circ} \mathrm{C}$ and $27.1 \mathrm{~J} / \mathrm{g}$, respectively, for $3 \mathrm{~h} . T_{\mathrm{m}}\left(166.0^{\circ} \mathrm{C}\right)$ of the 


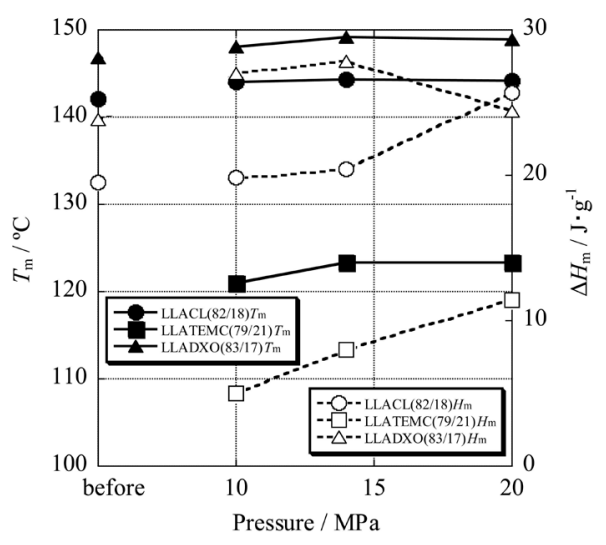

Figure 3. Change of $T_{\mathrm{m}}$ and $\Delta H_{\mathrm{m}}$ of L-LA copolymers under $\mathrm{scCO}_{2}$ at $40^{\circ} \mathrm{C}$ for $3 \mathrm{~h}$.

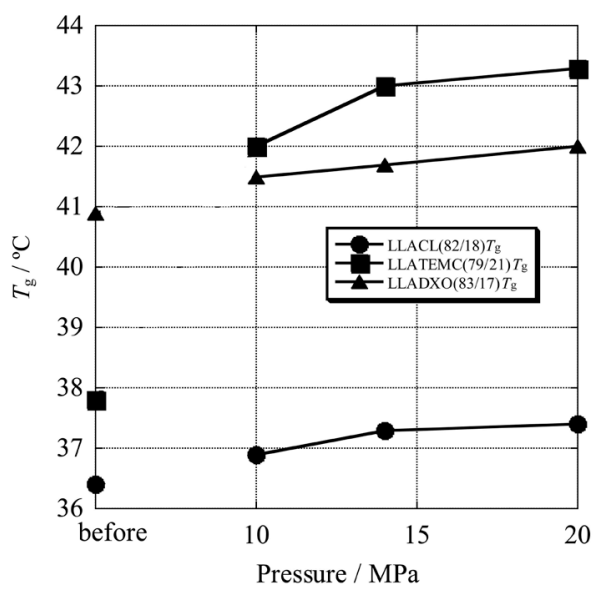

Figure 4. Change of $T_{\mathrm{g}}$ of L-LA copolymers under $\mathrm{scCO}_{2}$ at $40^{\circ} \mathrm{C}$ for $3 \mathrm{~h}$.

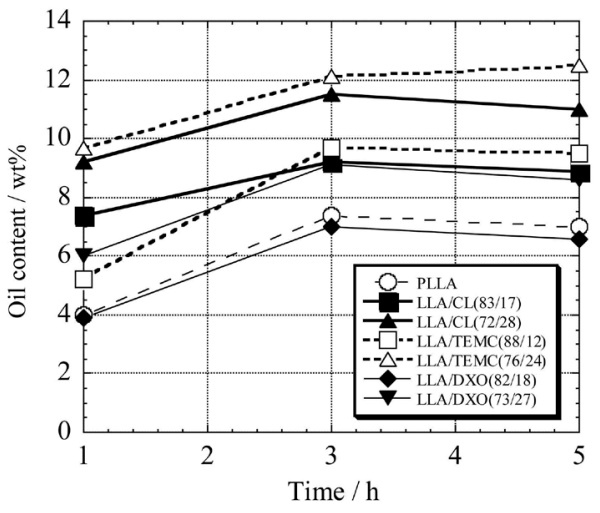

Figure 5. Effect of time on impregnation of L-LA copolymer film with essential oil using $\mathrm{scCO}_{2}$ at $40^{\circ} \mathrm{C}$ and $14 \mathrm{MPa}$.

poly(L-LA) for $5 \mathrm{~h}$ was barely different from the value for $3 \mathrm{~h}$. The changes of $T_{\mathrm{m}}$ and $\Delta H_{\mathrm{m}}$ over time have a relationship that is opposite to the change of content, as shown in Figure 5, and $T_{\mathrm{m}}$ and $\Delta H_{\mathrm{m}}$ are considered to affect content. Poly(L-LA-ran-CL) (83/17) had the same result, with the content reaching maximum (9.2\%) for 3 $\mathrm{h}$ when $T_{\mathrm{m}}$ became lower. Y. Tominaga et al. reported that $T_{\mathrm{m}}$ and $\Delta H_{\mathrm{m}}$ change under scCO 2 [34]. In our pre- 
vious report, in order to evaluate the relationship between $T_{\mathrm{m}}$ or $\Delta H_{\mathrm{m}}$ and content, we synthesized various L-LA copolymers with different $T_{\mathrm{m}}$ and $\Delta H_{\mathrm{m}}$, and investigated the difference in content [21] [22]. In the previous work, it appeared that the content of poly(L-LA-ran-TEMC) $(81 / 19)\left(T_{\mathrm{m}} 97.9^{\circ} \mathrm{C}\right.$ and $\left.-\Delta H_{\mathrm{m}} 5.1 \mathrm{~J} / \mathrm{g}\right)$, which was lower than $T_{\mathrm{m}}$ and $-\Delta H_{\mathrm{m}}\left(157.0^{\circ} \mathrm{C}\right.$ and $\left.36.0 \mathrm{~J} / \mathrm{g}\right)$ of poly(L-LA-ran-CL) (85/15), was higher than that of poly(L-LAran-CL).

After processing for $3 \mathrm{~h}$, the contents of all poly(L-LA-ran-TEMC)s increased more than the value for $1 \mathrm{~h}$; it was $12.1 \%$ for composition 76/24. The content for $5 \mathrm{~h}$ was almost the same as for $3 \mathrm{~h}$ in all poly (L-LA-ranTEMC)s. As with poly(L-LA-ran-CL), the impregnation of oil into poly(L-LA-ran-TEMC) by scCO reached its maximum for $3 \mathrm{~h}$. Poly(L-LA-ran-TEMC) (73/27) showed content lower than the other copolymers at same composition; it was $9.1 \%$ for $3 \mathrm{~h}$. Although the content in poly(L-LA-ran-DXO) increased for the first $3 \mathrm{~h}$ as did the other two kinds of copolymers, the content was almost the same over $3 \mathrm{~h}$. From the above results, it was understood that impregnation into poly(L-LA) copolymers of refined oil for $3 \mathrm{~h}$ is the optimum under $\mathrm{scCO}_{2}\left(40^{\circ} \mathrm{C}\right.$, $14 \mathrm{MPa})$.

\subsection{Effect of Temperature on Impregnation of Poly(L-LA) Random Copolymers with Essential Oil Using $\mathrm{ScCO}_{2}$}

The effect of processing temperature on impregnation was considered. Pressure and time were $14 \mathrm{MPa}$ and $3 \mathrm{~h}$, respectively, which were the optimal conditions in the above-described experiment. The impregnation experiment was conducted at $40^{\circ} \mathrm{C}, 60^{\circ} \mathrm{C}, 80^{\circ} \mathrm{C}$, or $100^{\circ} \mathrm{C}$. Oil impregnation into the poly(L-LA) copolymers was performed using the same method as above. The effect of temperature on oil impregnation into poly(L-LA) copolymers is shown in Figure 6. The horizontal axis expresses temperature and the vertical axis expresses the content of the essential oil. Although the content in poly(L-LA) was $7.4 \%$ at $40^{\circ} \mathrm{C}$, it increased to $14.2 \%$ at $100^{\circ} \mathrm{C}$ with an increase in temperature. The content of the oil for poly(L-LA-ran-CL) (83/17) was $8.3 \%$ at $40^{\circ} \mathrm{C}$, the $\log$ of the content increased proportionally to temperature, reaching $37.5 \%$ at $100^{\circ} \mathrm{C}$. The temperature and the content of poly(L-LA-ran-CL) (72/28), which is distinct from poly(L-LA-ran-CL) (83/17), were proportionality related in the range of $40^{\circ} \mathrm{C}$ to $100^{\circ} \mathrm{C}$, and showed $40.2 \%$ of maximum at $100^{\circ} \mathrm{C}$.

In poly(L-LA-ran-TEMC) $(86 / 14)$, the content was $9.7 \%$ at $40^{\circ} \mathrm{C}$ and it increased with an increase in temperature; it was $37.7 \%$ at $100^{\circ} \mathrm{C}$. Poly(L-LA-ran-TEMC) (76/24) showed the same impregnation curve as did poly(L-LA-ran-TEMC) (86/14) and the content increased with an increase in temperature. At $80^{\circ} \mathrm{C}$, the impregnated content in poly(L-LA-ran-TEMC) increased more rapidly than did that in poly(L-LA-ran-CL). This is because $T_{\mathrm{m}}$ and $\Delta H_{\mathrm{m}}$ of poly(L-LA-ran-TEMC) are lower at the same composition than for poly(L-LA-ranCL).

Although the impregnated content in poly(L-LA-ran-DXO) (82/18) was slightly lower than poly(L-LA-ranCL) (83/17) in all the temperature ranges, it was the almost same tendency. Since $T_{\mathrm{m}}$ and $T_{\mathrm{g}}$ of both copolymers have similar values for the same composition, it is thought that the content relative to temperature similarly change. The difference of the content of both copolymers would be attributable to $T_{\mathrm{m}}$ and $\Delta H_{\mathrm{m}}$. Although the

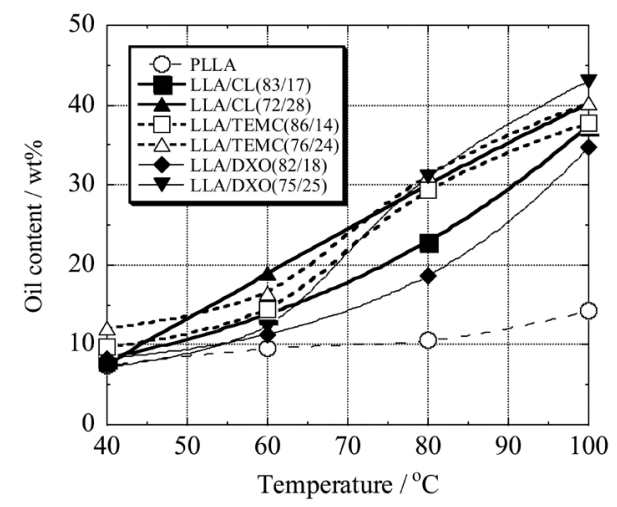

Figure 6. Effect of temperature on impregnation of L-LA copolymer film with essential oil using $\mathrm{scCO}_{2}$ at $40^{\circ} \mathrm{C}$ for $3 \mathrm{~h}$. 
content of poly(L-LA-ran-DXO) $(75 / 25)$ was $7.2 \%$ at $40^{\circ} \mathrm{C}$, it increased rapidly over $60^{\circ} \mathrm{C}$ and was $43.0 \%$ at $100^{\circ} \mathrm{C}$. The impregnation curve of poly(L-LA-ran-DXO) was similar to the shape of that of poly(L-LA-ranTEMC), showing that temperature affects content in a similar way. Since $T_{\mathrm{m}}\left(119.3^{\circ} \mathrm{C}\right)$ and $T_{\mathrm{g}}\left(25.4^{\circ} \mathrm{C}\right)$ of this copolymer is similar to the values $\left(T_{\mathrm{m}}\right.$ of $107.4^{\circ} \mathrm{C}, T_{\mathrm{g}}$ of $\left.28.4^{\circ} \mathrm{C}\right)$ of poly(L-LA-ran-TEMC) $(76 / 24)$, as described above, it is thought that the effect of temperature on content is dependent on $T_{\mathrm{m}}$ and $T_{\mathrm{g}}$ of the polymer.

In order to investigate the influence of the temperature of the physical properties of the copolymers under $\mathrm{scCO}_{2}$, the molecular weight and the thermal characteristic were studied at the range from $40^{\circ} \mathrm{C}$ to $80^{\circ} \mathrm{C}$. The copolymers of about $80 \%$ of L-LA content were used for the experiment. The experiments are under $\mathrm{scCO}_{2}$ at $14 \mathrm{MPa}$ for $3 \mathrm{~h}$ without the oil. Figure 7 shows change of a molecular weight. Although the molecular weight of three kinds of copolymers increased by abbreviation $0.15 \times 10^{4}$ by processing at $40^{\circ} \mathrm{C}$ rather than processing before, that over $60^{\circ} \mathrm{C}$ became lower than processing before inversely. This is considered that the low fragment of the molecular weight was removed by the extraction effect of $\mathrm{scCO}_{2}$ at a lower temperature, the increase in a molecular weight took place as a result, and transesterification or cleavage around terminal in main chain was induced rather than the extraction effect over $60^{\circ} \mathrm{C}$.

Figure 8 shows change of $T_{\mathrm{m}}$ and $\Delta H_{\mathrm{m}}$ for which it determined by first heating of DSC measurement. By scCO ${ }_{2}$ processing, although $T_{\mathrm{m}}$ and $\Delta H_{\mathrm{m}}$ of the copolymers were an upward tendency until $60^{\circ} \mathrm{C}$, they decreased at $80^{\circ} \mathrm{C}$. Therefore, it was found that crystallinity becomes the highest by processing at $60^{\circ} \mathrm{C}$ and $14 \mathrm{MPa}$. Furthermore, although poly(L-LA-ran-DXO) (79/21) was noncrystalline polymer without the melting point, it changed to crystalline polymer with the melting point by $\mathrm{scCO}_{2}$ processing. The appearance of a crystalline domain is considered that the rearrangement of a polymer chain is the cause.

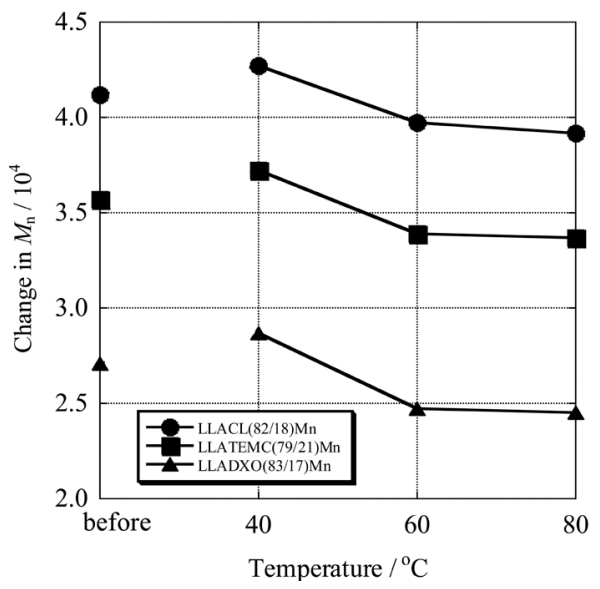

Figure 7. Change of $M_{\mathrm{n}}$ of L-LA copolymers under $\mathrm{scCO}_{2}$ at $40^{\circ} \mathrm{C}$ for $3 \mathrm{~h}$.

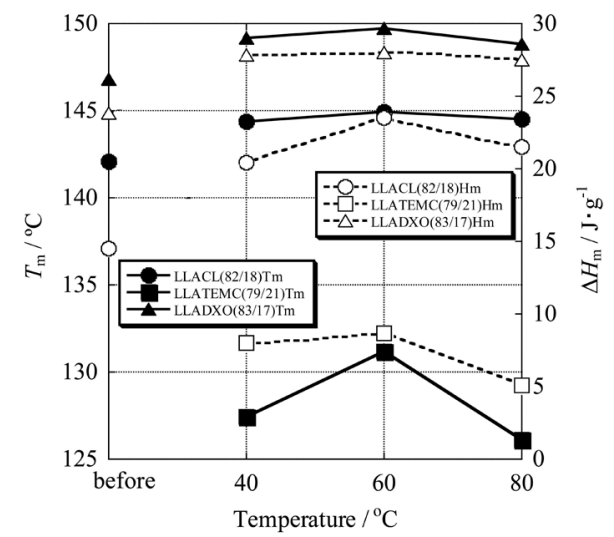

Figure 8. Change of $T_{\mathrm{m}}$ and $\Delta H_{\mathrm{m}}$ of L-LA copolymer under $\mathrm{scCO}_{2}$ at $40^{\circ} \mathrm{C}$ for $3 \mathrm{~h}$. 
Change of the glass transition point in the thermal characteristic is shown in Figure 9. As well as change of a molecular weight (Figure 7), $T_{\mathrm{g}}$ of all the copolymers became higher than processing before by processing at $40^{\circ} \mathrm{C}$ and $14 \mathrm{MPa}$, and the highest value was shown. Among them, $T_{\mathrm{g}}$ of poly(L-LA-ran-DXO) (79/21) went up by $5.2^{\circ} \mathrm{C}$. This is considered that the rearrangement of a polymer chain has influenced greatly as the occurrence of $T_{\mathrm{m}}$ (Figure 8). However, it can assume that $T_{\mathrm{g}}$ of these copolymers is falling in with temperature rise as $M_{\mathrm{n}}$, and is closely connected with the molecular weight. From the above result, the increase in the oil content with temperature rise is considered that plasticization of a copolymer has influenced greatly rather than the change in physical properties of a copolymer.

\section{Conclusions}

In this work, the factors influencing the impregnation of poly(L-LA) random copolymers with useful compounds were investigated under $\mathrm{scCO}_{2}$ using copolymers previously used. The effects of temperature, pressure, and time on the contents of useful compounds into copolymers were investigated. The polymer that was used as a base of this material was poly(L-LA-ran-CL), poly(L-LA-ran-TEMC), or poly(L-LA-ran-DXO). In the effect of pressure on impregnation using poly(L-LA-ran-CL), although oil impregnation into poly(L-LA) was $4.4 \%$ at $10 \mathrm{MPa}$, the oil content abruptly increased with an increase in pressure over $12 \mathrm{MPa}$, reaching a maximum of $7.4 \%$ at $14 \mathrm{MPa}$. Similarly, the essential oil content of other poly (L-LA-ran-CL)s showed a maximum value at $14 \mathrm{MPa}$. In the conventional experiment, although impregnation was only conducted at a pressure of $20 \mathrm{MPa}$, it turned out that pressure greatly affects the incorporation of essential oil. In the impregnation experiment with poly(L-LA-ran-CL), it was thought that the content would be highest at $14 \mathrm{MPa}$. The oil content of poly(L-LAran-TEMC) (88/12) increased with increased pressure and was 9.7\% of maximum at $14 \mathrm{MPa}$. Although the content of poly(L-LA-ran-CL) increased in proportion to pressure, the content of poly(L-LA-ran-TEMC) showed an abrupt increase in the range of 13 to $14 \mathrm{MPa}$. The contents of poly(L-LA-ran-DXO) exhibited a large change as well as the copolymers of other kinds at around $14 \mathrm{MPa}$, but the content was almost the same below $12 \mathrm{MPa}$ or over $17 \mathrm{MPa}$. The results were that the content of the three kinds of copolymers with L-LA reached a maximum at $14 \mathrm{MPa}$ in the impregnation of copolymers with refined oil extracted from Thujopsis dolabrata var. hondae under $\mathrm{scCO}_{2}$. Since the density of $\mathrm{scCO}_{2}$ rose with the increase in pressure, it was expected that the solubility to $\mathrm{scCO}_{2}$ of an organic compound also rose with the increase in pressure, but the content of oil was the maximum at $14 \mathrm{MPa}$. Therefore, it is considered that the physical properties of polymer have affected impregnation rather than the solubility of oil.

The effect of processing time the content was considered in the oil impregnation of various copolymers with L-LA. Although the content in poly(L-LA) was $4.0 \%$ for $1 \mathrm{~h}$, it increased to $7.4 \%$ for $3 \mathrm{~h}$. It was expected that content would increase with elongation of time. However, content barely changed; it was $7.0 \%$ for $5 \mathrm{~h}$. Other the poly (L-LA) copolymers were the same results. Since the oil remained in the reaction container after $5 \mathrm{~h}$, it is suggested that the oil was saturated within polymer for $3 \mathrm{~h}$. From the results of pressure and time, incorporation of oil can be said for the physical properties of polymer to have influenced.

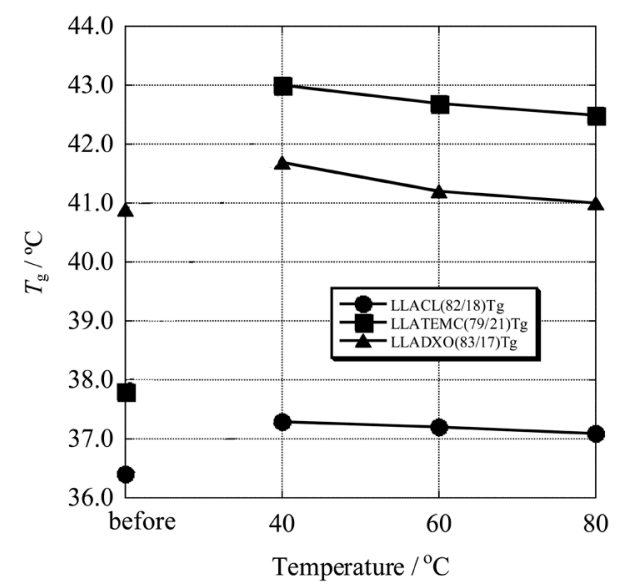

Figure 9. Change of $T_{\mathrm{g}}$ of L-LA copolymer under $\mathrm{scCO}_{2}$ at $40^{\circ} \mathrm{C}$ for $3 \mathrm{~h}$. 
The effect of processing temperature on impregnation was considered. Impregnation experiments were conducted at $40^{\circ} \mathrm{C}, 60^{\circ} \mathrm{C}, 80^{\circ} \mathrm{C}$, and $100^{\circ} \mathrm{C}$. Although the content in poly $(\mathrm{L}-\mathrm{LA})$ was $7.4 \%$ at $40^{\circ} \mathrm{C}$, it increased to $14.2 \%$ at $100^{\circ} \mathrm{C}$. The content in poly(L-LA-ran-CL) $(83 / 17)$ was $8.3 \%$ at $40^{\circ} \mathrm{C}$. Temperature and content were proportionately related up to $80^{\circ} \mathrm{C}$ but the content increased abruptly at $100^{\circ} \mathrm{C}$, reaching $37.5 \%$. The content in other poly(L-LA-ran-CL)s also increased with an increase in temperature. This experiment proved that the content could be increased by increasing the temperature. Poly(L-LA-ran-TEMC) (86/14) was 9.7\% of content at $40^{\circ} \mathrm{C}$, The content increased with an increase in temperature and was $37.7 \%$ at $100^{\circ} \mathrm{C}$. Poly(L-LA-ran-TEMC) (76/24) showed the same impregnation curve as did poly(L-LA-ran-TEMC) (86/14), meaning the content increased with an increase in temperature. The content in poly(L-LA-ran-TEMC) increased more rapidly than did that in poly(L-LA-ran-CL) at $80^{\circ} \mathrm{C}$. The reason for this is that $T_{\mathrm{m}}$ and $\Delta H_{\mathrm{m}}$ of poly(L-LA-ran-TEMC) are lower for the same composition than that of poly(L-LA-ran-CL).

The content in poly(L-LA-ran-DXO) (82/18) was almost the same as that in poly(L-LA) at $40^{\circ} \mathrm{C}$ and $60^{\circ} \mathrm{C}$, but it increased drastically over $80^{\circ} \mathrm{C}$. The impregnation curves of poly(L-LA-ran-DXO) (82/18) were the same shape as those of poly(L-LA-ran-CL) (83/17). Since $T_{\mathrm{m}}$ and $T_{\mathrm{g}}$ of both copolymers have similar values for the same composition, the changes of content related to temperature were gave similarly. Although the oil content was increase with an increase of temperature, the content was different from the changes of $T_{\mathrm{m}}$ and $\Delta H_{\mathrm{m}}$ against temperature. On the other hands, the increase of the content corresponds to the change of $T_{\mathrm{g}}$, fluidization of polymer with the rise of temperature is a consequence of the content increased. When these copolymers at the same composition were compared, the content of poly(L-LA-ran-CL) showed a value higher than did that of poly(L-LA-ran-DXO). $\Delta H_{\mathrm{m}}(36.7 \mathrm{~J} / \mathrm{g})$ of poly(L-LA-ran-DXO) (90/10) is higher than is that (28.6 J/g) of poly(LLA-ran-CL) (88/12). This shows that the crystallinity of poly(L-LA-ran-DXO) is high. From the results obtained we concluded that that crystallinity becomes high has suppressed impregnation to the copolymers of oil, and impregnation did not increase at higher pressure or longer processing time. On the other hand, $M_{\mathrm{n}}$ of used poly(L-LA) copolymers was almost changeless to all the parameters (pressure, time, and temperature) by $\mathrm{scCO}_{2}$ treatment. Therefore, it was shown that the thermal properties of the polymer would be affected the incorporation of oil into the polymer.

\section{Acknowledgements}

This work was supported by Ministry of Education, Culture, Sports, Science and Technology of Japan under Grantin-Aid for Scientific Research (C).

\section{References}

[1] Arciola, C.R., Campoccia, D., Speziale, P., Montanaro, L. and Costerton, J.W. (2012) Biofilm Formation in Staphylococcus Implant Infections: A Review of Molecular Mechanisms and Implications for Biofilm Resistant Materials. Biomaterials, 33, 5967-5982. http://dx.doi.org/10.1016/j.biomaterials.2012.05.031

[2] Vuong, C., Kocianova, S., Voyich, J.M., Yao, Y., Fischer, E.R., Deleo, F.R. and Otto, M. (2004) A Crucial Role for Exopolysaccharide Modification in Bacterial Biofilm Formation, Immune Evasion, and Virulence. The Journal of Biological Chemistry, 279, 54881-54886. http://dx.doi.org/10.1074/jbc.M411374200

[3] Oerlemans, C., Deckers, R., Storm, G., Hennink, W.E. and Nijsen, J.F.W. (2013) Evidence for a New Mechanism behind HIFU-Triggered Release from Liposomes. Journal of Controlled Release, 168, 327-333. http://dx.doi.org/10.1016/j.jconrel.2013.03.019

[4] Fredenberg, S., Jönsson, M., Laakso, T., Wahlgren, M., Reslow, M. and Axelsson, A. (2011) Development of Mass Transport Resistance in Poly(Lactide-co-Glycolide) Films and Particles-A Mechanistic Study. International Journal of Pharmaceutics, 409, 194-202. http://dx.doi.org/10.1016/j.ijpharm.2011.02.066

[5] Ghassemi, A.H., Steenbergen, M.J., Talsma, H., Nostrum, C.F., Jiskoot, W., Crommelin, D.J.A. and Hennink, W.E. (2009) Preparation and Characterization of Protein Loaded Microspheres Based on a Hydroxylated Aliphatic Polyester, Poly(Lactic-co-Hydroxymethyl Glycolic Acid). Journal of Controlled Release, 138, 57-63. http://dx.doi.org/10.1016/j.jconrel.2009.04.025

[6] Greco, F. and Vicent, M.J. (2009) Combination Therapy: Opportunities and Challenges for Polymer-Drug Conjugates as Anticancer Nanomedicines. Advanced Drug Delivery Reviews, 61, 1203-1213. http://dx.doi.org/10.1016/j.addr.2009.05.006

[7] Liu, R., Ma, G.H., Wan, Y.H. and Su, Z.G. (2005) Influence of Process Parameters on the Size Distribution of PLA Microcapsules Prepared by Combining Membrane Emulsification Technique and Double Emulsion-Solvent Evapora- 
tion Method. Colloids and Surfaces B: Biointerfaces, 45,144-153. http://dx.doi.org/10.1016/j.colsurfb.2005.08.004

[8] Shojaee, S.A., Rajaei, H., Hezave, A.Z., Lashkarbolooki, M. and Esmaeilzadeh, F. (2013) Experimental Investigation and Modeling of the Solubility of Carvedilol in Supercritical Carbon Dioxide. The Journal of Supercritical Fluids, 81, 42-47. http://dx.doi.org/10.1016/j.supflu.2013.04.013

[9] Machmudah, S., Zakaria, Winardi, S., Sasaki, M., Goto, M., Kusumoto, N. and Hayakawa, K. (2012) Lycopene Extraction from Tomato Peel by-Product Containing Tomato Seed Using Supercritical Carbon Dioxide. Journal of Food Engineering, 108, 290-296. http://dx.doi.org/10.1016/j.jfoodeng.2011.08.012

[10] Zhou, J., Han, S., Dou, Y., Lu, J., Wang, C., He, H., Li, X. and Zhang, J. (2013) Nanostructured Poly(l-Lactide) Matrix as Novel Platform for Drug Delivery. International Journal of Pharmaceutics, 448, 175-188. http://dx.doi.org/10.1016/j.ijpharm.2013.03.038

[11] George, K.A., Chirila, T.V. and Wentrup-Byrne, E. (2012) Effects of Crosslink Density on Hydrolytic Degradation of Poly(l-Lactide)-Based Networks. Polymer Degradation and Stability, 97, 964-971. http://dx.doi.org/10.1016/j.polymdegradstab.2012.03.017

[12] Nelson, M.T., Munj, H.R., Tomasko, D.L. and Lannutti, J.J. (2012) Carbon Dioxide Infusion of Composite Electrospun Fibers for Tissue Engineering. The Journal of Supercritical Fluids, 70, 90-99. http://dx.doi.org/10.1016/j.supflu.2012.06.007

[13] Elkovitch, M.D., Tomosko, D.L. and Lee, L.J. (1999) Supercritical Carbon Dioxide Assisted Blending of Polystyrene and Poly(Methyl Methacrylate). Polymer Engineering \& Science, 39, 2075-2084. http://dx.doi.org/10.1002/pen.11599

[14] Sauceau, M., Fages, J., Common, A., Nikitine, C. and Rodier, E. (2011) New Challenges in Polymer Foaming: A Review of Extrusion Processes Assisted by Supercritical Carbon Dioxide. Progress in Polymer Science, 36, 749-766. http://dx.doi.org/10.1016/j.progpolymsci.2010.12.004

[15] Areerat, S., Nagata, T. and Ohshima, M. (2002) Measurement and Prediction of LDPE/CO 2 Solution Viscosity. Polymer Engineering \& Science, 42, 2234-2245. http://dx.doi.org/10.1002/pen.11113

[16] Yang, J.T., Sang, Y., Chen, F., Fei, Z.D. and Zhong, M.Q. (2012) Synthesis of Silica Particles Grafted with Poly(Ionic Liquid) and Their Nucleation Effect on Microcellular Foaming of Polystyrene Using Supercritical Carbon Dioxide. The Journal of Supercritical Fluids, 62, 197-203. http://dx.doi.org/10.1016/j.supflu.2011.11.024

[17] Thote, A.J. and Gupta, R.B. (2005) Formation of Nanoparticles of a Hydrophilic Drug Using Supercritical Carbon Dioxide and Microencapsulation for Sustained Release. Nanomedicine: Nanotechnology, Biology and Medicine, 1, 85-90. http://dx.doi.org/10.1016/j.nano.2004.12.001

[18] Varona, S., Rodríguez-Rojo, S., Martín, Á., Cocero, M.J. and Duarte, C.M.M. (2011) Supercritical Impregnation of Lavandin (Lavandula hybrida) Essential Oil in Modified Starch. The Journal of Supercritical Fluids, 58, 313-319. http://dx.doi.org/10.1016/j.supflu.2011.06.003

[19] Schnitzler, J. and Egger, R. (1999) Mass Transfer in Polymers in a Supercritical $\mathrm{CO}_{2}$-Atmosphere. The Journal of Supercritical Fluids, 16, 81-92. http://dx.doi.org/10.1016/S0896-8446(99)00020-0

[20] Tsutsumi, C., Hara, T., Fukukawa, N., Oro, K., Hata, K., Nakayama, Y. and Shiono, T. (2012) Incorporation of L-Lactide Random Copolymers with Japanese Cypress Oil ( $\alpha$-Pinene) Using Supercritical Carbon Dioxide. Green Chemistry, 14, 1211-1219. http://dx.doi.org/10.1039/c2gc16546e

[21] Tsutsumi, C., Fukukawa, N., Sakafuji, J., Oro, K., Hata, K., Nakayama, Y. and Shiono, T. (2011) Impregnation of Poly(L-Lactide-ran-Cyclic Carbonate) Copolymers with Useful Compounds with Supercritical Carbon Dioxide. Journal of Applied Polymer Science, 121, 1431-1441. http://dx.doi.org/10.1002/app.33646

[22] Tsutsumi, C., Sakafuji, J., Okada, M., Oro, K. and Hata, K. (2009) Study of Impregnation of poly(L-Lactide-ran- $\varepsilon-$ Caprolactone) Copolymers with Useful Compounds in Supercritical Carbon Dioxide. Journal of Materials Science, 44, 3533-3541. http://dx.doi.org/10.1007/s10853-009-3477-9

[23] Maeda, Y., Nakayama, A., Arvanitoyannis, I., Kawasaki, N., Hayashi, K., Yamamoto, N. and Aiba, S. (2000) Synthesis of Characterization of Copoly(Succinic Anhydride-Ethylene Oxide)-Poly(L-Lactide) Block Copolymer. Polymer Journal, 32, 307-315. http://dx.doi.org/10.1295/polymj.32.307

[24] Vanhoorne, P., Dubois, P., Jerome, R. and Teyssie, P. (1992) Macromolecular Engineering of Polylactones and Polylactides. 7. Structural Analysis of Copolyesters of i $\varepsilon$-Caprolactone and L- or D,L-Lactide Initiated by Triisopropoxyaluminum. Macromolecules, 25, 37-44. http://dx.doi.org/10.1021/ma00027a008

[25] Nakayama, Y., Yasuda, H., Yamamoto, K., Tsutsumi, C., Jerome, R. and Lecomte, P. (2005) Comparison of Sm Complexes with Sn Compounds for Syntheses of Copolymers Composed of Lactide and Cyclic Carbonates and Their Biodegradabilities. Reactive and Functional Polymers, 63, 95-105. http://dx.doi.org/10.1016/j.reactfunctpolym.2005.02.012

[26] Tsutsumi, C., Nakagawa, K., Shirahama, H. and Yasuda, H. (2002) Enzymatic Degradations of Copolymers of L-Lactide with Cyclic Carbonates. Macromolecular Bioscience, 2, 223-232. 
http://dx.doi.org/10.1002/1616-5195(200206)2:5<223::AID-MABI223>3.0.CO;2-D

[27] Tsutsumi, C. and Yasuda, H. (2001) Biodegradation of Copolymers Composed of Optically Active L-Lactide and (R)or (S)-1-Methyltrimethylene Carbonate. Journal of Polymer Science Part A: Polymer Chemistry, 39, 3916-3927. http://dx.doi.org/10.1002/pola.10035

[28] Watanabe, Y., Shirahama, H. and Yasuda, H. (2004) Syntheses of Random and Block Copolymers of Lactides with 1,5-Dioxepan-2-One and Their Biodegradability. Reactive and Functional Polymers, 59, 211-224. http://dx.doi.org/10.1016/j.reactfunctpolym.2004.02.001

[29] Brunetti, L., Daghetta, A., Fedeli, E., Kikic, I. and Zanderighi, L. (1989) Deacidification of Olive Oils by Supercritical Carbon Dioxide. Journal of the American Oil Chemists Society, 66, 209-217.

[30] Andersson, M.B.O., Demirbuker, M. and Blomberg, L.G. (1997) Semi-Continuous Extraction/Purification of Lipids by Means of Supercritical Fluids. Journal of Chromatography A, 785, 337-343. http://dx.doi.org/10.1016/S0021-9673(97)00083-6

[31] Riha, V. and Brunner, G. (2000) Separation of Fish Oil Ethyl Esters with Supercritical Carbon Dioxide. The Journal of Supercritical Fluids, 17, 55-64. http://dx.doi.org/10.1016/S0896-8446(99)00038-8

[32] Mendes, M.F., Pessoa, F.L.P., Coelho, G.V. and Uller, A.M.C. (2005) Recovery of the High Aggregated Compounds Present in the Deodorizer Distillate of the Vegetable Oils Using Supercritical Fluids. The Journal of Supercritical Fluids, 34, 157-162. http://dx.doi.org/10.1016/j.supflu.2004.11.009

[33] Moura, J.M.L.N., Goncalves, L.A.G., Sarmento, L.A.V. and Petrus, J.C.C. (2007) Purification of Structured Lipids Using $\mathrm{SCCO}_{2}$ and Membrane Process. Journal of Membrane Science, 299, 138-145. http://dx.doi.org/10.1016/j.memsci.2007.04.035

[34] Tominaga, Y., Izumi, Y., Kwak, G.H., Asai, S. and Sumita, M. (2003) Effect of Supercritical Carbon Dioxide Processing on Ionic Association and Conduction in a Crystalline Poly(Ethylene Oxide)-LiCF $\mathrm{SO}_{3} \mathrm{Complex}_{\text {. Macromole- }}$ cules, 36, 8766-8772. http://dx.doi.org/10.1021/ma030207n 
Scientific Research Publishing (SCIRP) is one of the largest Open Access journal publishers. It is currently publishing more than 200 open access, online, peer-reviewed journals covering a wide range of academic disciplines. SCIRP serves the worldwide academic communities and contributes to the progress and application of science with its publication.

Other selected journals from SCIRP are listed as below. Submit your manuscript to us via either submit@scirp.org or Online Submission Portal.
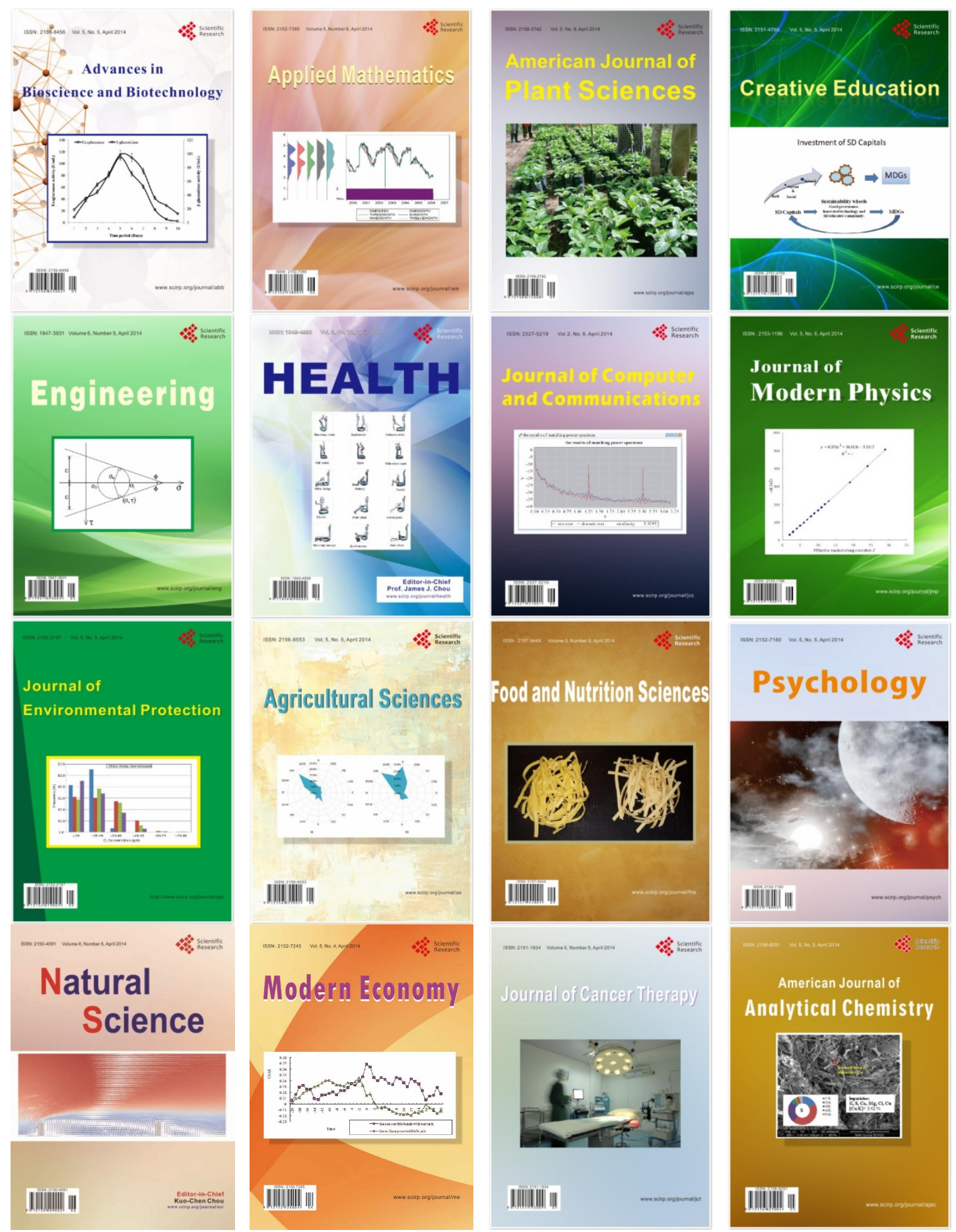